University of Nebraska - Lincoln

DigitalCommons@University of Nebraska - Lincoln

\title{
Effects of alliances, time, and network cohesion on the initiation of foreign sales by new ventures
}

Jifeng Yu

University of Nebraska-Lincoln, jifeng.yu@unl.edu

Brett Anitra Gilbert

Texas A\&M University, bagilbert@mays.tamu.edu

Benjamin M. Oviatt

University of New South Wales, mgtbbo@langate.gsu.edu

Follow this and additional works at: https://digitalcommons.unl.edu/managementfacpub

Yu, Jifeng; Gilbert, Brett Anitra; and Oviatt, Benjamin M., "Effects of alliances, time, and network cohesion on the initiation of foreign sales by new ventures" (2011). Management Department Faculty Publications. 106.

https://digitalcommons.unl.edu/managementfacpub/106

This Article is brought to you for free and open access by the Management Department at DigitalCommons@University of Nebraska - Lincoln. It has been accepted for inclusion in Management Department Faculty Publications by an authorized administrator of DigitalCommons@University of Nebraska - Lincoln. 


\title{
Effects of alliances, time, and network cohesion on the initiation of foreign sales by new ventures
}

\author{
Jifeng Yu, ${ }^{1}$ Brett Anitra Gilbert, ${ }^{2}$ and Benjamin M. Oviatt, ${ }^{3,4}$ \\ 1. College of Business, University of Nevada-Las Vegas, Las Vegas Nevada, USA \\ 2. Mays Business School, Texas A\&M University, College Station, Texas, USA \\ 3. Australian School of Business, University of New South Wales, Sydney, Australia \\ 4. J. Mack Robinson College of Business, Georgia State University, Atlanta, Georgia, USA
}

Corresponding author — Jifeng Yu, jifeng.yu@unl.edu

\begin{abstract}
In this study, we seek to advance the network perspective on new venture internationalization by examining the role of networks in accelerating new venture sales into foreign markets. We propose that knowledge derived from ventures' technology and marketing alliances increases the likelihood that new ventures begin exploiting opportunities in international markets. We also argue that the extent to which the networks open the venture to new knowledge or constrain it to knowledge already shared among the partners will influence the initiation of foreign sales by a venture. Using a longitudinal dataset of 118 ventures in the U.S. biotechnology industry, we confirm that different types of alliances (and, therefore, different types of knowledge - technology and marketing knowledge) differentially impact the likelihood of new venture internationalization. Moreover, network cohesion among venture alliances increases the likelihood that marketing alliances will promote initial foreign market sales, but decreases the likelihood that technology alliances will do so. Our research is a timely response to a call for the study of interactive effects among network structure, complex tasks, and time, and it provides a possible explanation for certain unexpected findings in studies that did not consider the effects of time.
\end{abstract}

Keywords: initiation of foreign sales, new ventures, technological knowledge, foreign marketing knowledge, alliances, network cohesion

\section{Introduction}

The ability to seize opportunities from foreign markets is increasingly important for establishing and maintaining a competitive advantage (Hymer, 1976; Zaheer, 1995; Sapienza et al., 2006). The task is a challenge requiring both the recognition of new opportunities and an understanding of how to obtain market share abroad (Jones and Coviello, 2005).
Early theories of internationalization suggest that firms pursue international expansion only after acquiring the knowledge and experiences on their own (Johanson and Vahlne, 1977). Recent research, however, is showing that a substantial number of new ventures internationalize at earlier stages in their life cycles (Brush, 1992; Isenberg, 2008; McDougall, 1989; McDougall, Shane, and Oviatt, 1994; Moen and Servais, 2002; Sapienza et al., 2006). A question 
that has intrigued scholars is how new ventures, with limited operational histories, gain the knowledge that is needed to exploit opportunities in foreign markets (Autio, Sapienza, and Almeida, 2000; Oviatt and McDougall, 2005).

Growing evidence suggests that the initiation of foreign sales by new ventures is enabled by the alliance networks to which the ventures belong (Bell, 1995; Coviello and Munro, 1995, 1997; Johanson and Vahlne, 2003). Coviello and Munro (1995), for example, observed that what appeared as a random and irrational pattern of foreign market entries by new and small businesses were actually rational behaviors driven by opportunities learned from interactions with network partners. Oviatt and McDougall (2005) noted that network partners are not only vital for creating awareness of attractive opportunities but also are increasingly important for helping new ventures move down the learning curve and accelerate their sales into foreign markets. The research on social network theory confirms that network relationships are active conduits of knowledge flows between business partners (Ahuja, 2000; Baum, Calabrese, and Silverman, 2000; DeCarolis and Deeds, 1999). Yet prior literature (e.g., Coviello and Munro, 1997; Knight and Cavusgil, 2004; Lu and Beamish, 2001) has not considered how differences in network structures and in the content of network ties influence the flow of knowledge that, in turn, influences the likelihood of new venture internationalization.

Recent research suggests the complexity of a task, the amount of time involved, and the connectivity of network partners interact to affect important outcomes (Lazer and Friedman, 2007; Soda, Usai, and Zaheer, 2004). Certainly, these factors affect new ventures in their efforts to internationalize. Building on these ideas, this study seeks to extend the network perspective on new venture internationalization by addressing three related research questions: (1) Do different types of knowledge exchanged among new ventures and their alliance partners affect venture internationalization differently? (2) Does time affect those relationships? (3) How does one structural aspect of the alliance network-its cohesion-alter the effects of that knowledge? We test hypothesized answers to those questions using longitudinal analyses on a sample of 118 biotechnology new ventures. We found the answer to the first question is, yes. Because of its greater uncertainty and complexity, the exchange of technological knowledge takes longer than marketing knowledge to influence novel outcomes in ventures, such as the initiation of foreign sales. Therefore, the answer to our second question is also, yes. Time does affect those relationships.

In answering the third question, our research design responds to Lazer and Friedman's (2007) recent call to empirically test the interactive effects of network structure, task complexity, and time on novel outcomes. We found network cohesion (more ties among a venture's alliance partners) inhibited the tendency of a venture's technology alliances to encourage venture internationalization. However, when marketing alliances were involved, we found cohesion promoted the initiation of foreign sales by a venture. The explanation is that the closer associations present among partners in a cohesive network can ensure the reliability of foreign marketing knowledge that is transferred in an alliance. However, when more complex technological knowledge is involved, sparse networks (i.e., few connections among venture partners) ensure the ventures develop capabilities from technological knowledge that is not widespread and, therefore, more likely to be novel. Such technology positions a new venture to compete more effectively in international markets.

By showing that the effect of network cohesion depends upon the type of knowledge exchanged among alliance partners and the time frame considered (short term or long term), we advance understanding of the complementary nature of structural holes theory (Burt, 1992) and network closure theory (Coleman, 1988). Our research adds new richness to the literature on international entrepreneurship by reinforcing the importance of time in the study of venture internationalization (Jones and Coviello, 2005) and showing the importance of understanding the content of knowledge that flows in venture alliances.

\section{Knowledge and the Initiation of Foreign Sales}

Theories of internationalization have traditionally proposed that firms develop the knowledge needed to internationalize operations "primarily through experience from [their own] current business activities in the market" (Johanson and Vahlne, 1990: 12). Devel- 
opments in network research, however, suggest that knowledge can transfer through a firm's alliance network (Powell, Koput, and Smith-Doerr, 1996). For example, Yli-Renko, Autio, and Sapienza (2001) found that young technology-based firms gain access to marketing and technological knowledge from key customer relationships, which demonstrates a strong role for alliance partners in helping young firms access knowledge. Tsang (2002) similarly showed that international relationships form channels for acquiring key knowledge. In fact, Nordberg, Campbell, and Verbeke (1996) suggested that learning and knowledge transfer are sometimes more important reasons for alliance formation than short-term economic rewards. These studies point to the conclusion that new ventures can and do accelerate their knowledge accumulation by leveraging knowledge from alliance partners.

The two types of knowledge known to motivate firm forays into international markets are technological and foreign marketing knowledge. Technological knowledge is the idea set "regarding scientific and technical advances on an applied, high-technology product" (Spencer, 2003: 219). This form of knowledge assists firms by enabling them to upgrade product quality, streamline operational efficiency, and improve innovation capacities (Knight and Cavusgil, 2004). Firms with strong technological knowledge can cultivate critical thinking and problem-solving skills that are used to develop technologies for foreign markets without incurring substantially more costs than they incur by operating solely in their own domestic market (Caves, 1971; Morck and Yeung, 1992). Technological capabilities also equip firms to modify products and operations under uncertain conditions, such as those faced when entering foreign markets (Autio et al., 2000; Sapienza, De Clercq, and Sandberg, 2005).

Foreign marketing knowledge, or organized and structured information about marketing in countries beyond a firm's home base ( $\mathrm{Li}$ and Calantone, 1998; Roth et al., 2009), is a second form of knowledge important for internationalization among both new ventures and established firms (Lord and Ranft, 2000; Oviatt and McDougall, 1995). Foreign marketing knowledge incorporates information about host countries' financial, cultural, social, and political conditions as well as general facts about country differences and how international business operations are conducted (Lord and Ranft, 2000; Makino and Delios, 1996). It is knowledge used by internationalizing firms to identify opportunities (Shane, 2000), alleviate perceptions of uncertainty (Erramilli and Rao, 1990), and better understand the new market context in which they would be selling. Empirical studies show a clear connection between a venture's international experience, the proxy commonly used for foreign marketing knowledge, and a venture's performance overseas (Bloodgood, Sapienza, and Almeida, 1996; Delios and Beamish, 2001), making foreign marketing knowledge another essential knowledge resource for a venture desiring to pursue international opportunities.

\section{Technology alliances and initiation of foreign sales by new ventures}

Technological alliances involve the development of joint routines and capabilities, the sharing of intellectual and scientific skills, and perhaps joint research and development (Ahuja, 2000; Hagedoorn and Duysters, 2002; Soh, 2003). Such alliances can provide access to novel ideas and complementary skills that reside within other firms. Yet, the utility of such relationships is rarely uniform, with high caliber partners providing more benefits than partners of lower caliber (Stuart, 2000). Ventures in relationships with strong technological partners are more likely to develop unique technological capabilities that help the venture establish advantages over competitors in foreign markets (Autio et al., 2000; Dunning, 1988).

Superior innovative abilities, however, do not transfer automatically from partner firm to subject firm. For example, Zaheer and Bell (2005) unexpectedly found, in a cross-sectional study, no direct performance effect for mutual fund companies that worked with the most innovative partners. Relative to other interfirm relationships, innovative technology alliances are more difficult to manage due to the complexity of technology components, the uncertainty associated with the pace and direction of technology development, and the possible conflict of interests among partnering firms (see Pisano, 1989). Transferring technology knowledge across organizational boundaries requires new routines, codes, and conventions to overcome barriers to effective collaboration. Thus, experience matters in these alliances (Anand and Khanna, 2000), and the benefits from alliances with superior technology partners may only manifest over time. While the Zaheer and Bell (2005) 
study was valuable in its unusual attention to both internal and network resources, its cross-sectional data was unable to reveal any advantages of time-dependent direct associations between companies and their innovative partners. The process of assimilating technology knowledge from an alliance is even more likely to be time consuming for the young ventures that are the focus of our study because they have more limited absorptive capacities (Cohen and Levinthal, 1990; Sapienza, et al., 2006; Todorova and Durisin, 2007; Zahra and George, 2002a). Accordingly, we hypothesize that:

Hypothesis 1: A venture's likelihood of initiating foreign sales a) increases with the technological knowledge of its technology partners; but b) the effect of technological knowledge is only observed over time.

\section{Marketing alliances and the initiation of foreign sales by new ventures}

Like its technological counterparts, marketing alliances foster interaction between involved parties, and constitute an important channel for knowledge flow and exchange (Chen and Huang, 2004; Larson, 1992). Marketing alliances can link firms that have valuable new technologies with firms that have valuable marketing information. The combination permits new product capabilities to be explored, new customers to be acquired, and currently unexplored markets to be reached (Lechner and Dowling, 2003; $\mathrm{Lu}$ and Beamish, 2001). Knowledge and benefits accrue both for firms wanting to expand into new markets and for their partners who want to profit from their marketing capabilities to distribute and sell new products and services.

The alliances between ventures that want to initiate foreign sales and their marketing partners may take a variety of forms: distribution arrangements, licensing agreements, joint ventures, and others. These marketing partners may be foreign-headquartered firms or firms headquartered in the same country as the venture but with international operations experience. Ventures without international experience must learn enough about the conduct of international business from these alliances to allay natural concerns of uncertainty (De Clercq, Sapienza, and Crijns, 2005). Their marketing partners must learn just enough about a venture's products and services to gain con- fidence that a business opportunity exists and how to exploit it in markets where they operate (Leung et al., 2005). Thus, knowledge important for successful foreign marketing can move in both directions between alliance partners (Simonin, 1999).

The foreign marketing knowledge a venture learns from a partner can pertain to the foreign markets where the partner operates. However, such knowledge, when filtered, absorbed, and integrated into the venture's existing knowledge stock is often useful for helping the venture enter other countries as well. For example, in studying the international operations of a large sample of service firms in Sweden, Eriksson et al. (1997: 352) concluded that "accumulated internationalization experience that affects both business knowledge and institutional knowledge, is not related to specific country markets. It is a firm-specific experience relevant to all markets." Jonsson and Elg's (2006) study of IKEA, the home furnishing firm, showed that the company applied what it learned from its operation in China to its subsequent entry into the Russian market. Multinational enterprises also commonly value and encourage market knowledge sharing among their units in different countries (Roth et al., 2009). Consistent with this logic, knowledge about foreign marketing derived from alliances increases with the number of such alliances a venture creates. By cooperating with more partners, a venture can access a richer pool of marketing knowledge from various contextual conditions, which enhances the firm's ability to promptly respond to unexpected market shifts, breeds confidence and stronger feelings of control, and reduces the perceived costs of internationalization.

Unlike technology alliances, which are often complex, multifaceted, and quite dynamic (Hagedoorn, 1993; Pisano, 1989), marketing alliances involve fewer unknowns because country cultures and international business practices are relatively well established and slower to change (Leung et al., 2005). Thus, marketing alliances with foreign firms are likely to aid a venture's initiation of foreign sales in a shorter period of time than technology alliances, and also are likely to continue to benefit the venture over time. Moreover, as a venture interacts with more foreign partners over time, its foreign marketing knowledge may increase sufficiently to exploit emerging opportunities in markets even beyond the foreign partner's operating area (Coviello and Munro, 1995). 
Domestic partners with international experience may provide similar short-term benefits for internationalizing operations. However, in the long term, the value of knowledge from these domestic partners could dissipate as the ventures themselves gain more and more beneficial international marketing knowledge from, and assume similar marketing features as their domestic partners, because they are both from the same home culture (De Clercq et al., 2005). Therefore, we propose that time has opposing effects on foreign partnerships and partnerships with internationally experienced domestic firms:

Hypothesis 2a: A venture's likelihood of initiating foreign sales a) increases with the marketing knowledge of its foreign marketing partners; and b) the effect of marketing knowledge endures over time.

Hypothesis 2b: A venture's likelihood of initiating foreign sales a) increases with the marketing knowledge of its internationally experienced domestic partners; but b) the effect of marketing knowledge decreases over time.

\section{Network cohesion, alliance partners, and the initia- tion of foreign sales}

The preceding discussions emphasize that knowledge that is more difficult to transfer from one firm to another takes longer to accomplish and, thus, longer to influence the initiation of foreign sales. Social network theories also propose that the utility of knowledge derived from partners commonly depends on the novelty of the knowledge the firm receives, or on the reliability of the knowledge, which is the extent to which the knowledge comes from a trustworthy source. Burt (1992) argued that novelty arises within a network when its constituent actors are loosely connected with one another, in other words, when the network is sparse. Reliability, on the other hand, results when actors are tightly connected with one another, in other words, when the network is cohesive (Coleman, 1988). Empirical support exists showing the benefits of both sparse and cohesive networks. For example, Zaheer and Bell (2005) identified the benefit of sparse networks for firm innovation, but failed to find benefits for network cohesion. The findings of Rowley, Behrens, and Krackhardt (2000) and Walker, Kogut, and Shan (1997) are the opposite, pro- viding support for the cohesion perspective, while lending none to the value of sparse network structure. Burt (2000) argued that the two types of network structures are complementary, with sparse networks being essential for finding novel knowledge and cohesive networks being important for absorbing and using it. Others have argued that the superiority of a particular network structure depends on the type of knowledge being transferred and the purposes for which it is used (Ahuja, 2000). In combining these ideas, we show in the following sections how network cohesion and its opposite, a sparse network, differentially impact the knowledge ventures receive from their alliance partners.

\section{Technological knowledge and network cohesion}

Coleman (1988) argues that network cohesion increases the value of knowledge by providing access to data from multiple sources, thereby testing the reliability of information (Echols and Tsai, 2005; Koka and Prescott, 2002). The theory further posits that cohesion promotes trust between partners because within close-knit networks, firms develop common behavioral norms (Echols and Tsai, 2005; Granovetter, 1992), which improve communication and facilitate the transfer of fine-grained, reliable knowledge. In cohesive networks, opportunism is often discouraged because news about one firm's opportunistic behavior spreads quickly to others (Ahuja, 2000). Cohesive networks, therefore, are governance mechanisms that protect against malfeasance (Granovetter, 1985; Simons and Ingram, 2000).

In sparse networks, on the other hand, a focal firm's partners do not know one another so there is less shared understanding of knowledge among partners and greater diversity of knowledge stocks (Burt, 1992). This network structure is said to provide greater opportunities for a venture to acquire novel knowledge, and having been observed empirically at the firm level (e.g., Hargadon and Sutton, 1997; Zaheer and Bell, 2005), its advantage is sometimes viewed as well established (Burt, 2000).

Nonetheless, scholars have found the association between network structure and valuable novelty to be dependent on contingencies, such as attributes of the collaborators (Fleming, Mingo, and Chen, 2007), the strength of the ties (Levin and Cross, 2004), and alternative forms of embeddedness (Rowley et al., 2000). An emphasis on contingencies is consistent 
with Ahuja's (2000) conclusion that knowing the type of knowledge flowing between partners and how it is used by organizations is essential to understanding whether sparse or cohesive networks are likely to be beneficial. Thus, we agree with Fleming et al.'s (2007) recent conclusion that the theoretical and empirical issues remain open for research.

Further supporting this conclusion and informing our research is a simulation by Lazer and Friedman (2007) that showed tightly connected and, therefore, relatively efficient networks - over time-yielded inferior performance. They found that dense networks distributed knowledge efficiently in the short term, but over time their lack of diversity meant less new knowledge was available to a focal firm. They called for empirical study to determine whether the effect would be observed outside a simulation. Further, the authors concluded that a performance outcome:

"...is contingent on the time scale of the task, as well as its complexity, factors not included in any of the studies that we have identified" (Lazer and Friedman, 2007: 687).

In light of this observation, the research reported here aims to empirically test the interactive outcome effects of network structure over time on different types of tasks or knowledge being conveyed within the network. The outcome we focus on is foreign sales initiation by relatively young firms. Our approach to interactions over time contrasts with prior empirical research (e.g., Burt, 2002; Soda et al., 2004) on networks and time in terms of subjects, effects, and emphasis. ${ }^{1}$

With regard to technological knowledge, firms in cohesive networks tend to converge on available initial solutions to a problem (Lazer and Friedman, 2007; Portes and Sensenbrenner, 1993), which can often result in a relatively small pool of technological knowledge, lead to competency traps, and constrain technological endeavors (Sorenson and Stuart, 2000). Thus, despite the fact that network cohesion may accelerate the transfer of technological knowledge within a network, over time it may limit a venture's motivation to search for alternative solutions and thereby minimize its exposure to the diverse forms of technological knowledge that can help it build its advantages in foreign markets. Although Ahuja (2000) found firm innovation benefited from a cohesive network of alliances, he was studying the largest chemical firms in the world, among which network cohesion was an important guard against the opportunism naturally expected from powerful partners who are simultaneously competitors. In our empirical setting of relatively small and new ventures whose very existence depends on their ability to source novel information, network cohesion could create a deadly competency trap. Indeed, Alvarez and Barney (2001) stressed the importance for new ventures to be a continual source of technological innovation to protect themselves and maintain successful relationships with potentially predatory partners. Therefore, we expect to find:

Hypothesis 3: Network cohesion a) decreases the positive effect of technological knowledge of its technology partners on the likelihood of venture initiation of foreign sales; and b) the effect of network cohesion increases over time.

\section{Foreign marketing knowledge and network cohesion}

In the foreign marketing context, as previously noted, the transfer of knowledge is less complex because it changes more slowly. Novelty is of less importance than in the technological context because foreign marketing knowledge is relatively static. Furthermore, novelty in marketing may not be desirable because new and unverified business knowledge increases uncertainty and unreliability, which can deter firms from internationalizing (Simonin, 1999). The ability to trust the word and behavior of partners becomes far more important in such circumstances. For foreign partners of new ventures, which commonly lack an extensive history, network cohesion can allay partners' concerns over the viability of the venture's operations. Similarly, from the venture's standpoint, network cohesion minimizes concerns about opportunism when working with foreign partners, whose quality and reliability may be less easily discerned than that of domestic partners' and whose presence overseas could make it easy for the foreign partner to exploit the venture's products overseas. In summary, foreign marketing

1. Burt (2002), for example, revealed the brief duration and performance effect of bridge ties among employees at a bank. Soda et al. (2004) showed the positive performance effect of current, but not past, structural holes and past, but not current, structural closure among temporary television production organizations. 
alliances encourage ventures to initiate foreign sales, while network cohesion circumvents many of the complications and communication delays that can arise between partners in different countries (Smith, Dickson, and Smith, 1991). These benefits are likely to immediately impact the likelihood that a venture initiates sales in international markets and should strengthen over time as the venture gains experience working with foreign partners they can trust (Simonin, 1999). Thus, we predict:

Hypothesis 4a: Network cohesion a) increases the positive effect of marketing knowledge from foreign partners on the likelihood of venture initiation of foreign sales; and b) the effect of network cohesion increases over time.

Under network cohesion, marketing alliances with internationally experienced domestic partners will likely provide similar benefits to the ventures in the short run. However, in the long run the value of domestic partners' foreign marketing knowledge and the value of cohesion will dissipate. As Simonin (1999: 471) argues, experience "sets the level of familiarity with the information content and context, and consequently favors the transferability of knowledge." So as a venture absorbs more knowledge about marketing from its domestic partners, having the shared country of origin may result in gradually similar thinking about foreign marketing. As the ventures age and learn more, depending on a cohesive network for reliable information about foreign marketing from internationally experienced domestic partners becomes less important because the ventures can draw on their own knowledge stock for that information. Foreign marketing knowledge from these partners is likely to be more indirect than knowledge that comes from foreign marketing partners. Thus, its value to the venture may be more limited than is true of knowledge from foreign marketing partners. Therefore, we hypothesize:

Hypothesis 4b: Network cohesion a) increases the positive effect of marketing knowledge from internationally experienced domestic partners on the likelihood of venture initiation of foreign sales; but b) the effect of network cohesion decreases over time.

\section{Methods}

\section{Sample and data}

The empirical setting for this research is the U.S. biotechnology industry. Given the level of technological sophistication of biotechnology firms, technological knowledge serves as an important input for these firms and has spawned high levels of alliance activity within this industry (DeCarolis and Deeds, 1999; Liebeskind et al., 1996). In the 1990s alone, over 1,000 formal research and marketing alliances were initiated by biotechnology startups (Plunkett, 2001). Biotechnology firms also face high research and development (R\&D) costs, which increases their urgency to explore foreign markets so as to spread those costs across a larger market base (Caves, 1971; Morck and Yeung, 1992; Mowery, Oxley, and Silverman, 1996). Although some biotechnology firms focus exclusively on $\mathrm{R} \& \mathrm{D}$, some are growth oriented and, therefore, interested in generating foreign sales revenue themselves (Qian and Li, 2003; Shan, 1990). For these reasons, new venture internationalization is not a rare event in the biotechnology industry.

To ensure that the ventures' internationalization behavior was not affected by differing laws, regulations, cultures, or other conditions in the home market, we only considered ventures with U.S. headquartered operations (Shrader, Oviatt, and McDougall, 2000). Like other researchers, in order to obtain a significant amount of information about a relatively large number of initial venture internationalizations, we focused on initial public offering (IPO) new ventures (Zahra, 1996), which we define as ventures that undertake an initial public offering within eight years after inception. IPO ventures have legal obligations to report to constituents their alliance and international initiatives and any information that could adversely affect their market performance, which makes them an attractive group of firms to use for this research. IPO ventures tend to be growth oriented, and, as such, are more likely than other ventures to have an interest in internationalizing.

We developed a comprehensive listing of U.S. biotechnology new ventures that undertook an IPO during the period 1990-2000 by searching the Recombinant Capital Biotechnology Database (ReCap), the Securities Data Corporation (SDC) Platinum Database, and BioScan databases. We checked U.S. Securities and Exchange Commission (SEC) filings, Lexis-Nexis 
news reports, and company Web sites to ensure the ventures fit our operational definition of new ventures, and we excluded from analysis any ventures that were founded as spin-offs, a result of merger and acquisition, or the subsidiary of an established firm.

In total, we identified 118 ventures that met all of the aforementioned criteria. We searched the following additional archival data sources to gather data for our primary variables of interest: Mergent Online, COMPUSTAT, Lexis-Nexis, U.S. Patent and Trademark Office, and SEC filings in its EDGAR database. ReCap and BioScan were the primary sources used to identify alliances since they have been found to be consistent with data obtained through primary data collection (Deeds and Hill, 1999; Santoro and McGill, 2005). The time period for which each focal venture is included in this study varies, but includes each year from the year of its incorporation to either the year of its first international sale or a given year (year 2004 for the one-year lagged models or year 2007 for the fiveyear lagged models, which are described below), whichever event came first. Annual data were gathered for each venture during its respective time period. The 118 ventures contributed 1,103 year observations for 1982 to 2004 . Additional data about the ventures' internationalization status were collected between years 2005 and 2007, which were used to test the five-year lagged models.

\section{Dependent variable and methodology}

The longitudinal nature of our data required the use of Cox proportional hazard models to test the hypothesized relationships (Greene, 1997; Wooldridge, 2002). Compared with conventional regression models, such duration models better fit our data for several reasons. First, duration models are appropriate for capturing the occurrence of an event, such as initiating sales in foreign markets. Conventional regression models are only appropriate for explaining status conditions for a static point in time. Second, duration models allow independent variables to vary over time rather than assume they are constant.
Third, conventional regression models assume a normal distribution, which was unlikely to be the case for events such as the internationalization process. We applied robust estimation of the Cox proportional model because with this sample, the independence of observations assumption was violated (Boone et al., 2004; Gimeno, 2004).

The dependent variable was calculated as the hazard (the instantaneous rate) of a venture beginning international sales, which was coded dichotomously with 1 indicating that the venture realizes an initial foreign sale, or 0 otherwise. ${ }^{2}$ The hazard rate is defined as

$$
h_{i}(t)=\lim _{\Delta t \rightarrow 0} \operatorname{Prob}(t, t+\Delta t) / \Delta t
$$

where $\operatorname{Prob}()$ is the probability of an event (here the initial foreign market sale) between time $t$ and $(t+\Delta t)$, given that firm $i$ has not generated foreign sales before $t$. Foreign sales were defined as sales revenue derived from exports or other foreign operations (Autio et al., 2000). Foreign sales have been commonly used in prior scholarship to measure firm internationalization (Autio et al., 2000; Hitt et al., 2006; Sullivan, 1994; Tallman and Li, 1996; Yu and Cannella, 2007). Following a long list of prior researchers, Sullivan (1994: 331) argued that "a company's foreign sales are a meaningful first-order indicator of its involvement in international business." The first foreign sale constitutes an initial milestone that a firm reaches in overseas expansion and signals the acceptance of the firm by foreign customers. Conceptually, compared with other indicators of internationalization such as foreign assets and foreign employees, the presence of foreign sales not only reflects its presence in international markets but also suggests its ability to succeed there. Practically, foreign sales are systematically reported by firms and are appropriate for interorganization comparison. A close look at our sample reveals all ventures that initiated foreign sales continued sales abroad thereafter. Thus, foreign sales are not one-time events for our ventures, but rather are true indicators of beginning involvement in foreign markets. ${ }^{3}$

2. We constructed another measure of foreign market entry based on the venture's ratio of foreign sales to total sales. The measure was coded 1 if the ratio was greater than or equal to five percent, 0 otherwise. The pattern of results was essentially the same, and so we only report results from analysis without the degree of internationalization since this offers a more general analysis.

3. While some may argue that an alliance with a foreign partner is its first foray into internationalization, our data do not suggest that new ventures always utilize foreign partners for international sales purposes, at least not immediately. Many of the ventures did not generate sales in the short term after establishing alliances with foreign partners. Thus, for our purposes, foreign sales are a better indicator of whether the ventures had entered foreign markets. 
We searched COMPUSTAT, Mergent Online, ReCap, BioScan, and SEC filings (e.g., prospectus) to determine the incorporation date. Date of first foreign sale was determined from COMPUSTAT and SEC filings. Some ventures in our sample did not have an international sale between their incorporation and the end of our study in 2007. However, our statistical analysis appropriately corrects for the data censoring problem (Greene, 1997; Wooldridge, 2002).

\section{Independent variables}

\section{Technology expertise of technological alliance partners}

Building on prior research (Stuart, 2000), we measured the technological strength of a venture's technological alliance partners as the aggregate number of patents obtained by partners during the five years preceding each observation year. Patents are widely recognized as a valid indicator of a firm's technological capabilities (Ahuja and Katila, 2001; Bresman, Birkinshaw, and Nobel, 1999; DeCarolis and Deeds, 1999; Griliches, 1990), especially for biotechnology firms (Baum et al., 2000; Shan, Walker, and Kogut, 1994). The span of five years is consistent with earlier studies of biotechnology firms (Rothaermel and Deeds, 2004). Patent data were obtained from the U.S. Patent and Trademark Office Web site. In total, we identified 144,885 patents. We recognized a venture's technological alliances as those involving a technological component (Ahuja, 2000; Hagedoorn, 1993) using the ReCap and BioScan categorizations. We verified the nature of these alliances with information from the SEC filings, and found the data to be highly consistent. When discrepancies occurred, we relied on SEC filings since these documents are legally required. Alliance duration data were verified using Lexis-Nexis and SEC filings. For alliances for which termination data were indeterminate, we applied the rules established by Ahuja (2000), assuming joint ventures are long-lasting relationships and contractual agreements are short term. If no termination data for a joint venture was found, that relationship was assumed to continue. If no termination data for a contractual agreement was found, we assumed that the agreement existed until its last year documented or one year after its formation, whichever occurred later. Over 30,000 electronic news reports and thousands of SEC filings were used to verify these data.
Marketing alliances with foreign firms

Our theoretical development argues that marketing alliances are valued for their potential to inform new ventures of opportunities that exist in new markets, in this case foreign markets, and for the knowledge of international marketing and business operations they provide. Most network research examining the effect on firm outcomes of a specific type of tie has found the number of ties a focal firm has is an important determinant of the desired outcome (Baum et al., 2000; Lee, Lee, and Pennings, 2001). Consistent with this research, we proxy the foreign marketing knowledge derived from foreign firms as a count of the number of marketing alliances with these firms that a venture has in each year it is in the sample. Data about partners' national identity were gathered from COMPUSTAT, Lexis-Nexis, organizational Web sites, and SEC filings. In keeping with previous studies (Soh, 2003), we defined marketing alliances as interfirm cooperative agreements intended for marketing and distribution purposes. Again, we identified these alliances through ReCap, BioScan, and SEC filings, and applied the same process described in the prior section to verify duration data for each marketing alliance.

Relative to established firms, new ventures have limited history and resources, which prevented them from forming a large number of marketing alliances. In fact, our data showed that the majority of observations in our sample had no more than two marketing alliances with foreign firms and two marketing alliances with domestic firms with international experience. Given the limited number of marketing alliances held in any given year, there is no concern over new ventures being overextended in their ability to manage a large alliance network, and, therefore, no need to test for a curvilinear effect of the marketing alliances. Thus, we conducted all analyses based on the linear effect.

Marketing alliances with internationally experienced domestic firms

To measure the foreign marketing knowledge coming from internationally experienced domestic firms, we counted the number of internationally experienced domestic marketing partnerships held by the ventures in each year of the study. A domestic 
marketing partner was conceived as internationally experienced if it had engaged in international operations before its alliance with the focal venture. Data from COMPUSTAT, Lexis-Nexis, organizational Web sites, and SEC filings were used to find partner national identity and international activities. The same data sources and data collecting procedures were applied as explained above.

\section{Network cohesion}

We gauged the cohesion of a venture's network by the sum of the "constraint" of each of a venture's relations (Burt, 1992; Gargiulo and Benassi, 2000; Zaheer and Bell, 2005). The formula for constraint is

$$
C_{i j}=\left[P_{i j}+\sum_{q}\left(P_{i q} P_{q j}\right)\right]^{2}, \quad i \neq j
$$

where $P_{i j}$ is the proportion of venture $i$ 's alliance network represented by its alliance with firm $j . P_{i j}$, for example, is 0.33 if venture $i$ has a network of three partners. $P_{i q} P_{q j}$ accounts for the alliances among venture $i$ 's partners. Burt (1992) uses the term "constraint" to mean a limit on the possibility of finding a structural hole in a network by the existence of an alliance. Every alliance, by definition, eliminates a hole that could have been filled by an actor seeking to earn benefits as a broker of knowledge between parts of a network. Thus, a high value of $\sum_{j} C_{i j}$ indicates high cohesion in venture i's network. In other words, under this condition, there are fewer structural holes available in the network. This measure was calculated based on relationships present in each year the venture is included in the data. As before, we used Lexis-Nexis and SEC filings to determine ongoing alliances.

\section{Time}

The influence of differing lengths of time on the associations between two forms of alliances and the initiation of foreign sales is a distinctive aspect of our research. Thus, a lagged model structure was necessary. All independent variables were lagged by one year to test for the short-term impact of al- liance networks and by five years ${ }^{4}$ to test for longterm effects.

To test the Hypotheses 3, 4a, and $4 b$, we meancentered the variables before creating the interaction terms (Aiken and West, 1991).

\section{Control variables}

\section{Institutional relationships}

We included two control variables to count the number of relationships the venture had with U.S. governmental institutions as well as with academic and research institutions. These relationships differ from commercial ties, but may also help new ventures enter foreign markets early in their history. Data were gathered from each year the venture was in the sample using ReCap and BioScan for the relevant information.

\section{Venture size}

We controlled for venture size, which influences internationalization (Bloodgood et al., 1996). Consistent with prior studies (e.g., Gomes and Ramaswamy, 1999), this variable was measured as the natural logarithm of total assets held by the venture in each respective year. The data were collected from COMPUSTAT, SEC filings, and Mergent Online.

\section{Venture age}

The international business literature has suggested there are two different effects of organizational age on firm internationalization. On the one hand, firms accumulate experience with increased age, which tends to reduce the risks and cost of internationalization (Eriksson et al., 1997; Johanson and Vahlne, 1977, 1990). On the other hand, firms that enter international markets early in their life cycles may enjoy the learning advantages of newness (Autio et al., 2000; Sapienza et al., 2006). Given the opposing predictions of the arguments, we included both venture age and its square term in the analysis. Venture age was measured as the number of years since founding. The data were collected from SEC filings and Mergent Online.

4. Given the product life cycle in the biotechnology industry (from identifying drug candidates to various phases of clinical testing), it commonly takes five years, or even more, for a firm to fully take advantage of a new idea or technology (Giovannetti and Morrison, 2000). 


\section{Venture performance}

A new venture's foray into foreign markets is likely to be, at least partially, an outcome of its financial performance. Following prior studies (Geletkanycz and Hambrick, 1997; Hitt, Hoskisson, and Kim, 1997), we included each new venture's return on assets (ROA) for each year as a control variable. Relevant information was collected from COMPUSTAT, SEC filings, and Mergent Online.

\section{Venture technological capability}

A venture's own expertise in developing important technologies may minimize the need for partners and enable the venture to internationalize in an early period of its history. To control for this possibility, we included as a control variable the number of patents obtained by each venture in a five-year window preceding each observation year. The patent information was collected from the U.S. Patent \& Trademark Office.

\section{RED expense}

$R \& D$ expenditure may have two possible effects on a venture's internationalization. It may facilitate technology development, enabling early internationalization. On the other hand, R\&D spending may reduce resources available for overseas expansion, perhaps delaying a venture's initial foreign sales. Thus, we included R\&D expenditure as a control variable. We collected the data from COMPUSTAT and SEC filings.

\section{Industry dummies}

Based on the first two-digits of the North American Industry Classification System (NAICS) code, the ventures belonged to four different industry sectors. We used three dummy variables, IND32 (chemicals manufacturing), IND33 (computer and electronic products manufacturing and medical equipment and supplies manufacturing), and IND54 (professional, scientific, and technical services industry) to control for the industry effects. The base industry is health care and social assistance, sector 62 in NAICS code.
International experience of entrepreneurs/top managers/ founders

Several published papers (e.g., Carpenter and Fredrickson, 2001; Reuber and Fischer, 1997) suggest that personal international experience may motivate and facilitate early venture internationalization. We controlled for this effect by counting in each venture the number of entrepreneurs, top managers, and founders with international experience as of its IPO year. For ventures without prospectus information, data were obtained from the earliest SEC filings with manager information.

IPO year

The occurrence of IPOs may provide firms the funding that enables internationalization. Thus, we used a dummy variable to indicate the year when the focal venture undertook its IPO. The variable was coded 1 if the focal firm had gone through IPO in an observation year, 0 otherwise. The data were collected from COMPUSTAT and SEC filings.

Three control variables (ROA, firm size, and R\&D expense) had missing values primarily in the initial three years after the ventures' incorporation. Overall, approximately 10 percent of the data were missing from each of the three variables; however, pairwise deletion would have resulted in the loss of more than one-half of the sample. Additionally, dropping observations with missing values would have limited the sample to the youngest ventures since older ones were more likely to have missing values for the early years. Therefore, we employed multiple imputation (MI) techniques to replace missing values (Rubin, 1987). Compared with conventional mean substitution, MI is desirable because it includes a random component that enables it to yield unbiased estimates. Five sets of data were imputed and iteratively analyzed. The results were combined and are reported below.

\section{Results}

Table 1 presents descriptive statistics and correlations for the principal variables. The high correlation between firm age and IPO suggests that multicolinearity could be a potential problem in our analysis. To test for multicolinearity, we checked the variance inflation factors (VIFs) and found that the VIF values for firm age and its squared term were above the 


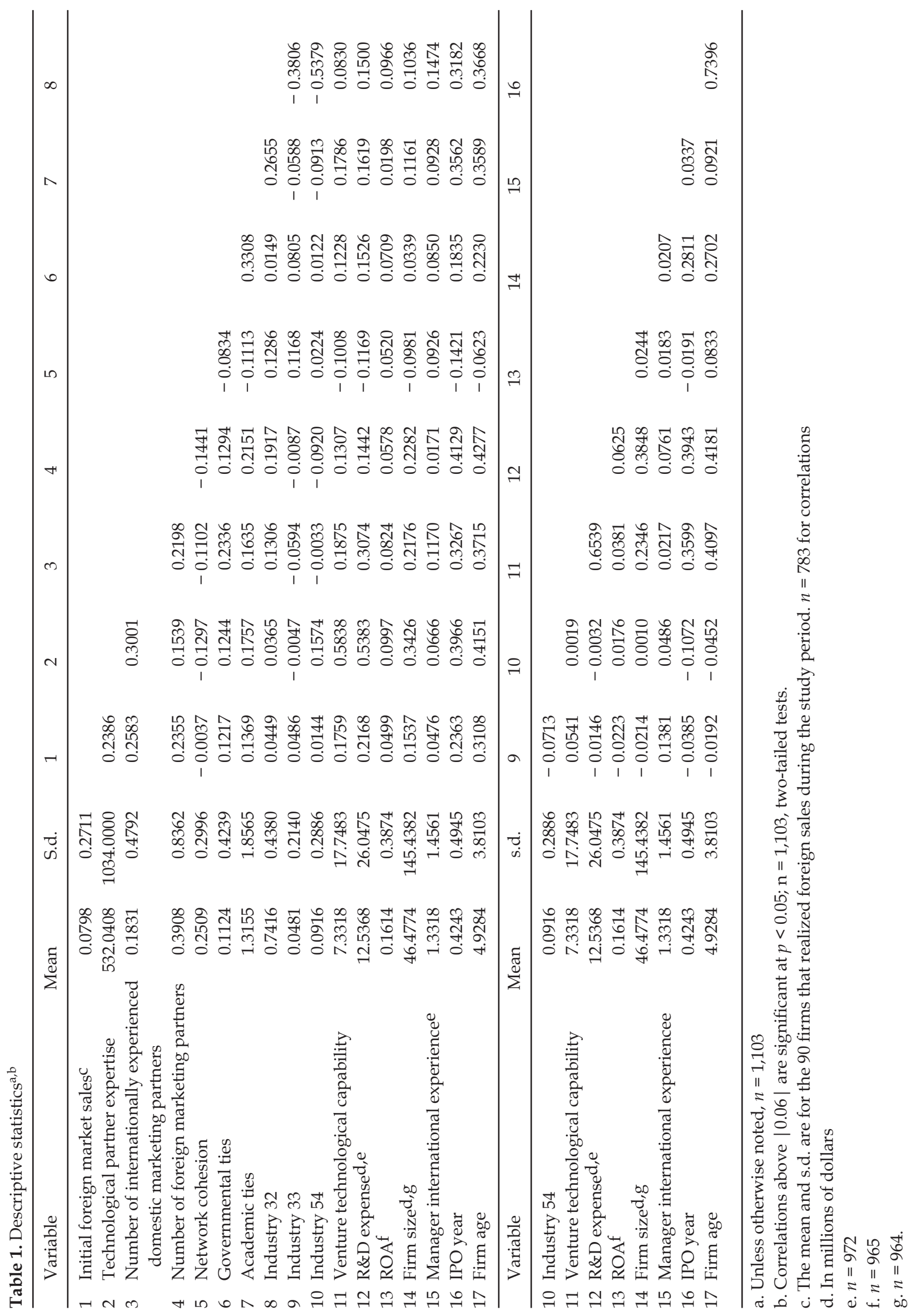


rule-of-thumb cutoff of 10 (no others were over 3.8). Thus, we also estimated models without the control for firm age. The results were almost identical to those reported here, which suggests that multicolinearity is not a concern for the analyses.

The issue of endogeneity could pose another problem to our models since networking is a strategic choice of firms; hence, we conducted Wu-Hausman tests and Durbin-Wu-Hausman tests. The tests show that we cannot reject the null hypotheses that the network variables are exogenous. Further, Sargan tests show that there is no overidentification problem with the instruments we used, which are the control variables in the models and their one-year lag terms.

Kaplan-Meier analysis in Figure 1 illustrates how quickly the ventures entered foreign markets. Approximately 15 , or 13 percent, of the 118 ventures made their initial foreign sales within five years of incorporation. At the end of the study, 90 ventures had sold in foreign markets.

Table 2 reports the results of Cox proportional models testing the above hypotheses. Models 1 and 4 are the baseline models, consisting only of the control variables, for the one-year lagged analysis and the five-year lagged analysis, respectively. Few of the control variables, several of which highlight internal venture capabilities, have significant effects on the initiation of a venture's foreign sales. The exception is the venture's age. In the models with one-year lags, the older ventures in our sample, which are the ventures with relatively more experience and established presence in the industry, are more likely than the younger ventures to initiate foreign sales. However, that effect decreases after a venture is 11 years old and is not relevant in the five-year lag models.
The log-likelihood ratio tests show the inclusion of the main effect and interaction terms each significantly improved model fit. Thus, we use the full models (Models 3 and 6) for the interpretation of our results because these models provide a more complete and rigorous test of the hypothesized effects and offer the greatest explanatory power (Bowen and $\mathrm{Wi}$ ersema, 2004).

Hypothesis 1 states that the technological expertise of the technological alliance partners increases a venture's odds of initiating foreign sales and this effect is only observed over time. Model 3 in Table 2 shows that the coefficient for this variable is positive but not statistically significant, indicating that, in the short term, the technological ability of the technological alliance partners does not have a significant impact on the likelihood of new venture international sales. This finding is consistent with that of Zaheer and Bell (2005). In line with the hypothesis, the coefficient for the variable in Model 6 is positive and significant $(p<0.05)$, suggesting that, in the long term, partnering with technologically strong firms confers benefits that lead new ventures to sell in international markets. Model 6 suggests an increase of one unit of technological partner expertise multiplies the probability (the baseline hazard) of international sales by $1.11\left(=\mathrm{e}^{0.1052}\right)$, that is an increase of 11 percent, in the long run. Together, these results lend support to Hypothesis 1 .

Hypothesis 2a predicts that the establishment of marketing alliances with foreign firms increases a venture's propensity to initiate foreign sales and this effect endures over time. Consistent with the hypothesis, Model 3 in Table 2 shows that the coefficient for the number of foreign partners is positive and sig-

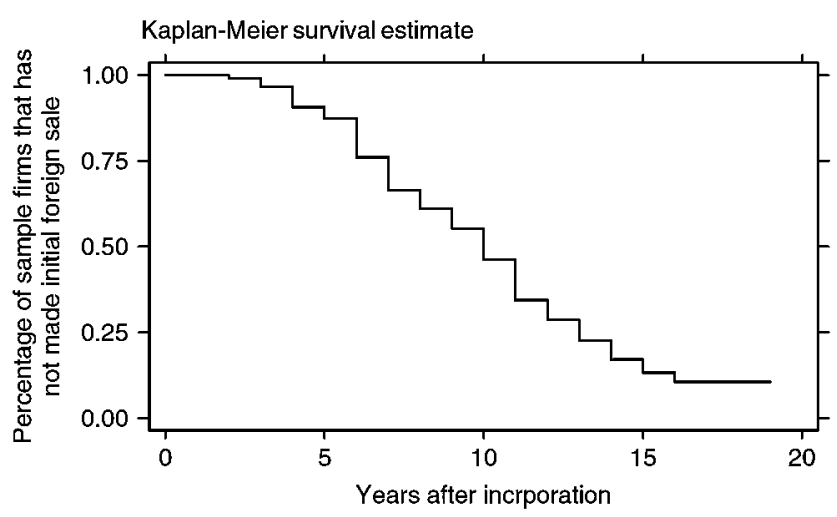

Figure 1. Kaplan-Meier survival estimate of time to initial foreign market sales. 
Table 2. Effects of alliance partners and network cohesion on the likelihood on venture initiation of foreign sales ${ }^{\mathrm{a}}$

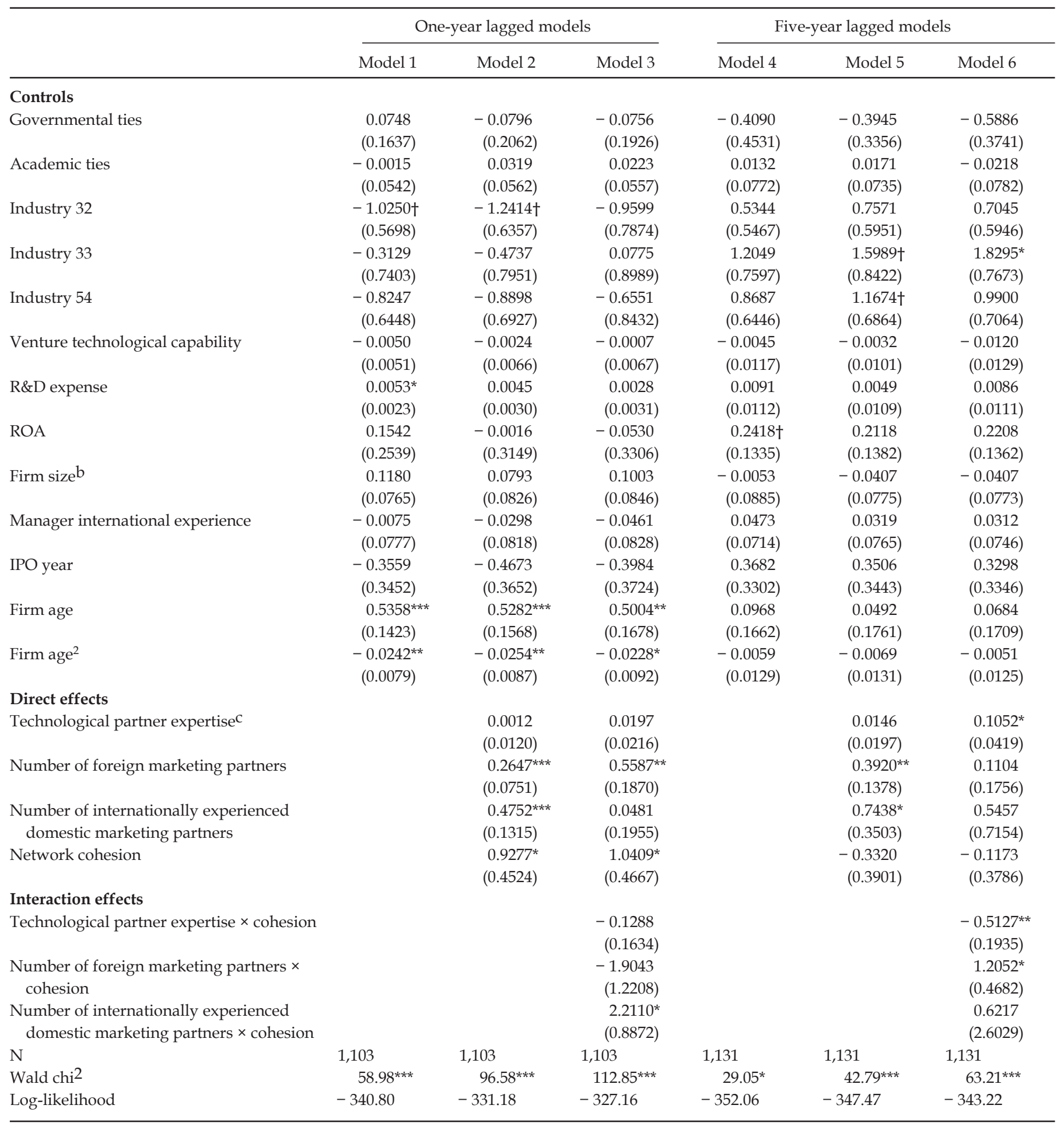

a. Robust estimates of standard errors are in parentheses.

b. Logarithm

c. Scaled by 0.01

$\dagger \mathrm{P}<0.10 ;{ }^{*} \mathrm{P}<0.05 ;{ }^{* *} \mathrm{P}<0.01 ;{ }^{* * *} \mathrm{P}<0.001$ 
nificant $(p<0.01)$, which suggests that an increase of one marketing alliance with foreign firms multiplies the probability (the baseline hazard) of international sales by $1.75\left(=\mathrm{e}^{0.5587}\right)$, or an increase of 75 percent, in the short term. Over time, the coefficient for this variable is not significant in Model $6(p=0.53)$, which only provides partial support for Hypothesis $2 \mathrm{a}$.

Hypothesis $2 \mathrm{~b}$ asserts that the knowledge exposure from the marketing alliances with internationally experienced domestic firms leads to foreign sales. However, the coefficient for this variable is not significant in either model $(p=0.81$ in Model $3 ; p=0.45$ in Model 6). This hypothesis is not supported.

Hypothesis 3 proposes that network cohesion negatively moderates the positive effect of technological alliance partner expertise on the likelihood of venture initiating international sales, and that negative moderation increases over time. Model 3 shows a nonsignificant coefficient. However, Model 6 shows a negative and significant $(p<0.01)$ coefficient for the interaction term between technological partner expertise and network cohesion. The Chow test rejected the null hypothesis that the coefficients were the same $(p$ $<0.001)$. Figure 2 visually depicts the results of the interaction (Aiken and West, 1991). The graph shows that given partner technological strength, a venture is less likely to commence international sales when net- work cohesion is high, providing strong support for Hypothesis 3.

Hypothesis 4a posits that network cohesion positively moderates the positive effect of foreign marketing alliance partnerships on the likelihood of a venture beginning international sales and this effect strengthens over time. The results in Model 3 indicate that network cohesion did not interact with foreign marketing partnerships to influence ventures' propensity for international sales in the short term. In the long term, however, represented by Model 6, network cohesion significantly $(p<0.05)$ interacts with foreign marketing partners such that ventures with foreign partners in cohesive networks were more likely to initiate foreign sales. A Chow test corroborated the difference of the coefficients in the two models $(p<0.001)$. Figure 3 depicts the plot of the interaction. The graph shows that given the number of marketing alliances with foreign firms, in the long term, a venture is more likely to initiate international sales when network cohesion is high. Thus, Hypothesis 4 a is supported.

Hypothesis $4 \mathrm{~b}$ indicates that network cohesion positively moderates the effect of internationally experienced domestic firms on the likelihood of a venture initiating international sales but this effect decreases over time. As anticipated by the hypothesis,

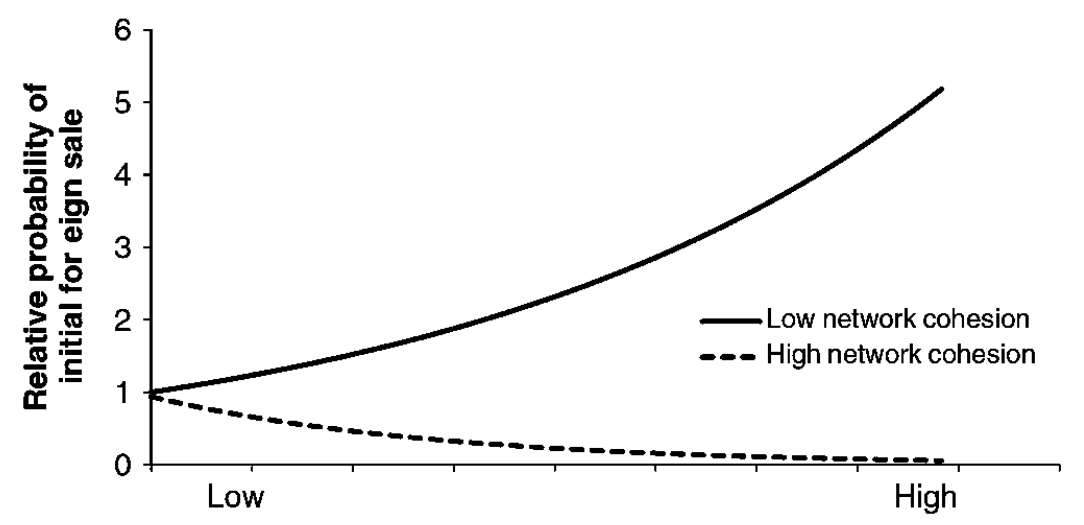

Technological partner expertise

Figure 2. Interaction between network cohesion and technological partner expertise (five-year lagged model). The vertical axis of the graph represents the probability of initial foreign sale relative to baseline hazard rate. The data range for network cohesion and for technological partner expertise are from one standard deviation above the mean (high) to one standard deviation below the mean (low) for each independent variable respectively. The actual lower-bound value for technological partner expertise is $-5.02(5.32-10.34)$. We set the lower-bound to zero as the value could not be negative. The actual lower-bound value for network cohesion is $-0.05(0.25-0.30)$. We set the lower-bound to zero as the value could not be negative. 


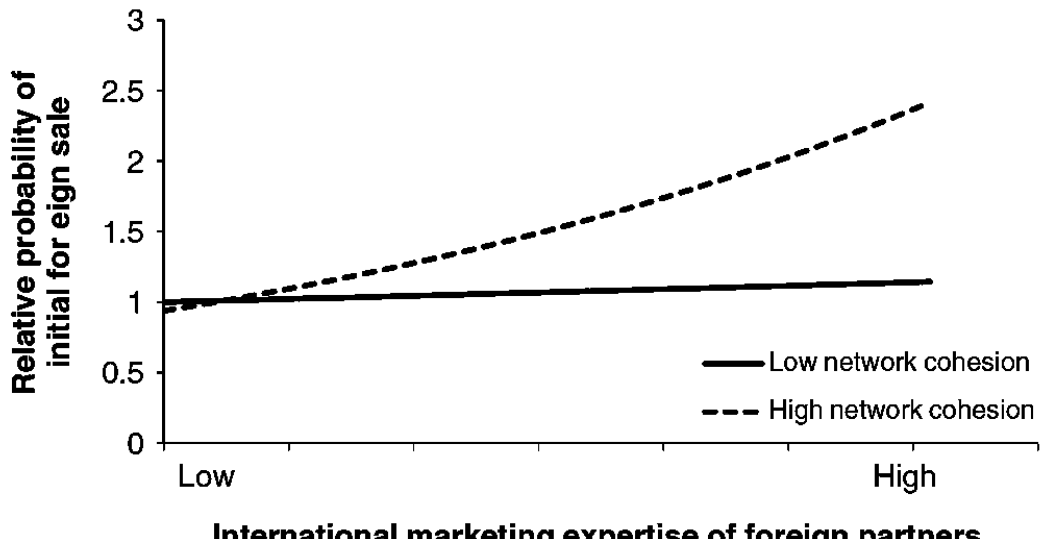

International marketing expertise of foreign partners

Figure 3. Interaction between network cohesion and the number of foreign marketing partners (five-year lagged model). The vertical axis of the graph represents the probability of an initial foreign sale relative to baseline hazard rate. The data range for network cohesion and for foreign partners are from one standard deviation above the mean (high) to one standard deviation below the mean (low) for each independent variable respectively. The actual lower-bound value for foreign partners is -0.45 ( $0.39-0.84$ ). We set the lower-bound to zero as the value could not be negative. The actual lower-bound value for network cohesion is -0.05 $(0.25-0.30)$. We set the lower-bound to zero as the value could not be negative.

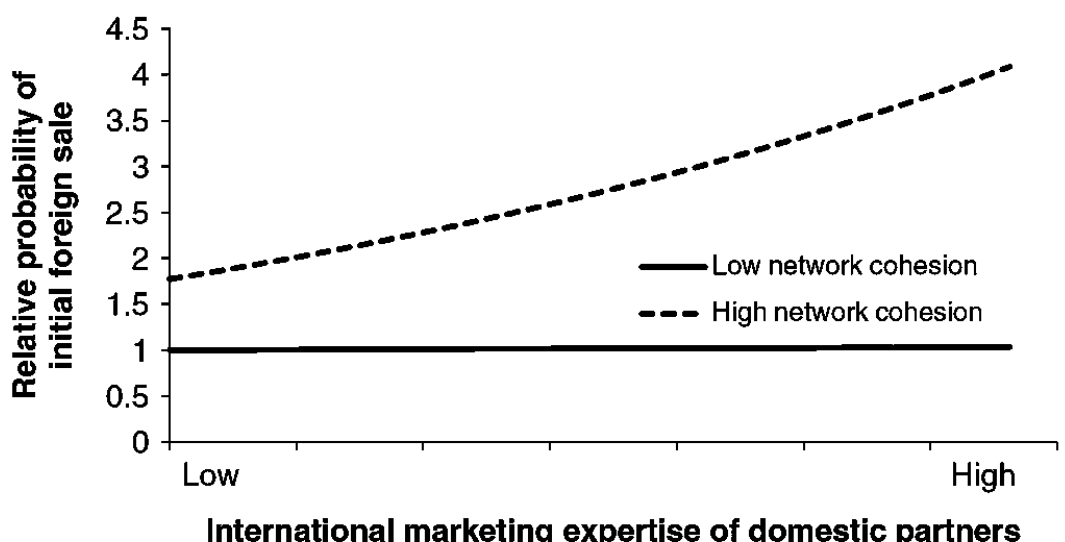

Figure 4. Interaction between network cohesion and the number of internationally experienced domestic marketing partners (oneyear lagged model). The vertical axis of the graph represents the probability of an initial foreign sale relative to baseline hazard rate. The data range for network cohesion and for domestic partners are from one standard deviation above the mean (high) to one standard deviation below the mean (low) for each independent variable respectively. The actual lower-bound value for internationally experienced partners is $-0.30(0.18-0.48)$. We set the lower-bound to zero as the value could not be negative. The actual lower-bound value for network cohesion is $-0.05(0.25-0.30)$. We set the lower-bound to zero as the value could not be negative.

the results in Model 3 show that network cohesion did significantly interact with internationally experienced domestic firms $(p<0.05)$ in such a way that high network cohesion and a relatively large number of marketing alliances with internationally experienced domestic firms were associated with a higher propensity to start international sales. The coefficient of the cross-product of network cohesion and internationally experienced domestic firms in Model 6, however, was not significant. A Chow test for the difference in the coefficients between the two models was statistically significant $(p<0.001)$. Figure 4 graphi- 
cally depicts the results of the interaction. The graph shows that in the short term, given high cohesion in a network with a relatively large number of marketing alliances involving internationally experienced domestic firms, a venture is more likely to initiate internationalization. The absence of significance for this variable in Model 6 suggests this benefit erodes over time and is consistent with the hypothesized shortterm effect of network cohesion on the relationship between internationally experienced domestic partners and ventures' likelihood of initial foreign sales.

\section{Discussion and Conclusion}

This research sought to understand how new venture technological and marketing alliances influence the likelihood that a venture initiates sales in international markets. Technological alliances provide relatively rapidly changing and complex technological knowledge that is important for establishing an advantage over indigenous foreign competitors (Autio et al., 2000). Marketing alliances, on the other hand, provide relatively stable knowledge for helping ventures conduct business operations successfully in international markets.

Unlike prior studies where researchers relied on differences in industries to compare different types of tasks and knowledge requirements, our empirical work demonstrates a more direct test of different knowledge types, and, therefore, differences in task complexity and dynamics within a single industry (cf. Rowley et al., 2000). We found direct and interactive effects associated with these types of knowledge that have not been observed in the past.

Specifically, as hypothesized, we found it takes time for a venture to realize foreign sales directly from the establishment of technological alliances. These results with their emphasis on the effects of time may explain why Zaheer and Bell (2005) did not find an expected direct relationship between firm alliances and innovation. It was not possible for their cross-sectional design to observe the interfirm transfer of new knowledge over time. As would be expected and according to our hypothesis, we also found foreign sales are more likely to be initiated by a venture after establishing a marketing alliance with a foreign firm. A surprising result of this study was the lack of support for a direct effect by internationally experienced domestic partners. A check for outliers showed nothing significant. One possible explanation is that since alliances are established for specific strategic purposes (Hagedoorn, 1993), internationally experienced domestic partners may be leveraged more for their ability to provide knowledge concerning the domestic market rather than as a source of direct knowledge about achieving sales in foreign markets. Naturally, the ventures may defer to their foreign marketing partners for directly relevant foreign marketing knowledge.

Our research also responds to the recent call to empirically explore the interactive effects of time and differences in tasks on social networks and novel firm outcomes (Lazer and Friedman, 2007). We found that in the long term, technological knowledge interacts negatively with network cohesion, while foreign marketing knowledge interacts positively. These empirical findings at the firm level are consistent with their theoretical simulations.

Within the network literature, it has been common for scholars to pit Burt's (1992) structural holes theory against Coleman's (1988) theory of network closure. Using a contingency approach, a small group of studies has explored the effect of network holes, but with mixed empirical evidence. For example, Zaheer and Bell (2005) identify the benefit of structural holes, but fail to support the notion of network closure. The findings of Rowley et al. (2000) and Walker et al. (1997) provide support for the network closure perspective, while lending none to the value of structural holes. Our research confirms that these theories are not at odds but, rather, are complementary, depending on the type of knowledge involved, as some recent publications suggest (Ahuja, 2000, Burt, 2000, Zaheer and George, 2004). Without such a test, comparisons of studies that seemed complementary could, instead, be explained by differences in industries, firm strategies, or internal firm conditions. See, for example, Ahuja's (2000) and Burt's (2000) comparisons. In addition, our study is unique in its focus on ventures' local network effects on the initiation of foreign sales, while others studied outputs such as productivity (e.g., Reagans and Zuckerman, 2001), personal networks (e.g., Reagans and McEvily, 2003), and industry networks (e.g., Schilling and Phelps, 2007).

Burt's (1992) theory of structural holes appears to have greater utility in settings where complex 
knowledge changes rapidly and novelty, rather than reliability, is the beneficial factor. Coleman's (1988) theory of network closure is more relevant in stable environments, where reliability is the determining factor. By exploring two different types of knowledge that are transferred through alliance network partners and accounting for network structure effects, the empirical work reported here is unique in showing network cohesion can encourage but also retard new venture sales in international markets.

Our findings, by distinguishing two knowledge types (i.e., technology and marketing-oriented knowledge), suggest that the effects of time on network structure may be more complex than are shown by Soda et al. (2004). They found current structural holes and past structural closure to be associated with positive organizational performance. Our research shows the transfer of marketing knowledge from a foreign partner has an immediate, although not a long-term, positive effect on the initiation of foreign sales. That effect is enhanced within cohesive alliance networks in the long term because, we believe, trust among partners is developed over time. We also show it can take time for the transfer of technological knowledge to have a positive effect on the initiation of foreign sales. However, the effect is inhibited in cohesive alliance networks because, we believe, diverse thought is constrained. Thus, exploration of complex models of the relationship between time and network structure seems warranted.

The study extends research on international entrepreneurship by contributing evidence in support of the network perspective on new venture internationalization and by providing a longitudinal analysis of the phenomenon (Coviello and Munro, 1997; Zahra and George, 2002b). This contribution is important because most of the studies examining new venture internationalization (e.g. Autio et al., 2000; Zahra, Ireland, and Hitt, 2000) explore it on the basis of firm economics. The economic perspective suggests that a new venture's internationalization is motivated by its own existing knowledge base and is exploited for the purpose of technology development without regard for the venture's social environment. This study shows that a venture's network relationships are important beyond economic and other firmspecific factors. The research also confirms that both network content and network structure (e.g., Rodan and Galunic, 2004) are important influences on venture outcomes.

The results also show the importance of explicitly incorporating the effects of time into analyses of new venture internationalization (Jones and Coviello, 2005). The international entrepreneurship literature reflects an implicit focus on time because it often focuses on the speed at which new ventures enter foreign markets (Oviatt and McDougall, 2005). Our research shows the probability of a venture initiating foreign sales may very well be altered by the technological and marketing relationships it establishes and by the time required for new ventures to process knowledge needed to exploit international opportunities.

\section{Implication for management practice}

Recent studies suggest that new ventures can improve growth prospects by quickly tapping opportunities overseas (Autio et al., 2000). The results of this study provide insight to managers of new ventures on the alliance network factors that aid internationalization endeavors. Venture managers interested in foreign markets should be especially alert for technological knowledge that is not widely shared among their alliance partners, because it is unique knowledge that is most valuable for building the competencies needed to succeed in international markets. Moreover, marketing alliances with foreign firms are likewise useful for initiating a venture's internationalization efforts since they provide knowledge of foreign operations that helps both the ventures and their partners exploit the best opportunities available. However, one caveat is that it is important for those partners to have connections with the venture's other partners to ensure reliability of the knowledge and to protect against opportunism. In other words, entrepreneurs are advised to leverage the foreign partners of their partners when investigating opportunities in foreign markets.

\section{Limitations and future research}

Although the results of this study largely corroborate theoretical expectations, there are several limitations associated with the design of this study that provide direction for future research. The study relies upon ventures competing in the U.S. biotechnology industry. This constraint was necessary to make 
the network constructs more compatible and easier to interpret. While we expect the findings of this study to apply to other high-tech firms, that expectation remains an empirical question that needs to be explored. Likewise, it would be worthwhile to test whether alliances of new ventures in more mature industries, such as the retailing industry, have the same effects that were found here.

A second limitation is that the results of this study are based on a unique group of firms, IPO new ventures. The choice of IPO new ventures ensured data were available on ventures' international behaviors and alliance activities for each year until the venture went international. Data from such high potential ventures are valuable in their own right because those firms produce significant innovations and employment for the economy. However, IPO new ventures, given their growth orientation, likely have greater propensities to internationalize than is true of privately held biotechnology firms. Thus, the generalizability of the findings may be limited.

Our measure for manager international experience may not fully encapsulate the experience held within the venture. Data for this variable were collected from the earliest SEC filings with relevant information on managers. However, due to manager turnover, the managers identified from the prospectus and other post-IPO documents can differ from those who started the ventures. Given the difficulty of collecting information about managers before IPO, this study made an effort to partially control this effect.

This study suggests several additional avenues for future research. First, in addition to the likelihood of initiating foreign sales, some other dimensions of internationalization, such as degree of internationalization (the percentage of total revenue derived from foreign markets) and scope of internationalization (the number of countries in which a venture operates) also deserve attention. It would also be valuable to examine how a venture's alliance network influences its degree and scope of internationalization through longitudinal analyses.

Second, this study only focuses on alliance relationships at the firm level. It would be interesting to examine how a venture's informal social network ties at the individual level influence the choices of countries entered and when that entry occurs. It would also be useful to know more about how venture internationalization influences social networks over time
(Slotte-Kock and Coviello, 2010). Future research should also examine the influence of other factors (e.g., organizational structure, domestic strategy) on new venture internationalization over time.

Alliance networks affect knowledge transfer among partners and internationalization among new ventures. However, given the time and complexity of creating and transferring knowledge, we hope our research encourages future work on these concepts.

Acknowledgments - This research was funded in part by the Ewing Marion Kauffman Foundation. The contents of this publication are solely the responsibility of the authors.

\section{References}

Ahuja G. 2000. Collaboration networks, structural holes, and innovation: a longitudinal study. Administrative Science Quarterly 45(3): 425-455.

Ahuja G, Katila R. 2001. Technological acquisitions and the innovation performance of acquiring firms: a longitudinal study. Strategic Management Journal 22(3): 197-220.

Aiken LS, West SG. 1991. Multiple Regression: Testing and Interpreting Interactions. Sage: Thousand Oaks, CA.

Alvarez SA, Barney JB. 2001. How entrepreneurial firms can benefit from alliances with large partners. Academy of Management Executive 15(1): 139-148.

Anand BN, Khanna T. 2000. Do firms learn to create value? The case of alliances. Strategic Management Journal, March Special Issue 21: 295-315.

Autio E, Sapienza HJ, Almeida JG. 2000. Effects of age at entry, knowledge intensity, and imitability on international growth. Academy of Management Journal 43(5): 909-924.

Baum JAC, Calabrese T, Silverman BS. 2000. Don't go it alone: alliance network composition and startups' performance in Canadian biotechnology. Strategic Management Journal, March Special Issue 21: 267-294.

Bell J. 1995. The internationalization of small computer software firms. European Journal of Marketing 29(8): 60-75.

Bloodgood JM, Sapienza JH, Almeida JG. 1996. The internationalization of new high-potential U.S. ventures: antecedents and outcomes. Entrepreneurship Theory \& Practice 20(4): 61-76.

Boone C, Olffen WV, Witteloostuijn AV, Brabander BD. 2004. The genesis of top management team diversity: selective turnover among top management teams in Dutch newspaper publishing, 1970-94. Academy of Management Journal 47(5): 633-656. 
Bowen HP, Wiersema MF. 2004. Modeling limited dependent variables: methods and guidelines for researchers in strategic management. In Research Methodology in Strategy and Management (Volume 1), Bergh D, Ketchen DJ (eds). Elsevier: Oxford, UK; 87-134.

Bresman H, Birkinshaw J, Nobel R. 1999. Knowledge transfer in international acquisitions. Journal of International Business Studies 30(3): 439-462.

Brush CG. 1992. Factors motivating small companies to internationalize: the effect of firm age. PhD. diss. Boston University, Boston, MA.

Burt RS. 1992. Structural Holes: The Social Structure of Competition. Harvard University Press: Cambridge, MA.

Burt RS. 2000. The network structure of social capital. In Research in Organizational Behavior, (Volume 22), Sutton RI, Staw BM (eds). JAI Press: Greenwich CT; 345-423.

Burt RS. 2002. Bridge Decay. Social Networks 24: 333-363.

Carpenter MA, Fredrickson JW. 2001. Top management teams, global strategic posture, and the moderating role of uncertainty. Academy of Management Journal 44(3): 533-545.

Caves RE. 1971. International corporations: the industrial economics of foreign investment. Economica 38(149): $1-27$.

Chen H, Huang Y. 2004. The establishment of global marketing strategic alliances by small and medium enterprises. Small Business Economics 22(5): 367-377.

Cohen WM, Levinthal DA. 1990. Absorptive capacity: a new perspective on learning and innovation. Administrative Science Quarterly 35: 128-152.

Coleman JS. 1988. Social capital in the creation of human capital. American Journal of Sociology 94: 95-120.

Coviello NE, Munro HJ. 1995. Growing the entrepreneurial firm: networking for international market development. European Journal of Marketing 29(7): 49-61.

Coviello NE, Munro HJ. 1997. Network relationships and the internationalisation process of small software firms. International Business Review 6(4): 361-386.

DeCarolis DM, Deeds DL. 1999. The impact of stocks and flows of organizational knowledge on firm performance: an empirical investigation of the biotechnology industry. Strategic Management Journal 20(10): 953-968.

De Clercq D, Sapienza HJ, Crijns H. 2005. The internationalization of small and medium-sized firms. Small Business Economics 24: 409-419.

Deeds DL, Hill CWL. 1999. An examination of opportunistic action within research alliances: evidence from the biotechnology industry. Journal of Business Venturing 14(2): 141-163.

Delios A, Beamish PW. 2001. Survival and profitability: the roles of experience and intangible assets in foreign sub- sidiary performance. Academy of Management Journal 44(5): 1028-1038.

Dunning JH. 1988. The eclectic paradigm of international production: a restatement and some possible extensions. Journal of International Business Studies 19: 1-31.

Echols A, Tsai W. 2005. Niche and performance: the moderating role of network embeddedness. Strategic Management Journal 26(3): 219-238.

Eriksson K, Johanson J, Majgard A, Sharma D. 1997. Experiential knowledge and cost in the internationalization process. Journal of International Business Studies 28: 337-360.

Erramilli MK, Rao CP. 1990. Choice of foreign market entry modes by service firms: role of market knowledge. Management International Review 30(2): 135-150.

Fleming L, Mingo S, Chen D. 2007. Collaborative brokerage, generative creativity, and creative success. Administrative Science Quarterly 52: 443-475.

Gargiulo M, Benassi M. 2000. Trapped in your own net? Network cohesion, structural holes, and the adaptations of social capital. Organization Science 11(2): 183-196.

Geletkanycz MA, Hambrick DC. 1997. The external ties of top executives: implications for strategic choice and performance. Administrative Science Quarterly 42(4): 654-681.

Gimeno J. 2004. Competition within and between networks: the contingent effect of competitive embeddedness on alliance formation. Academy of Management Journal 47(6): 820-842.

Giovannetti GT, Morrison SW. 2000. Convergence: The Biotechnology Industry Report. Ernst \& Young: Palo Alto, CA.

Gomes L, Ramaswamy K. 1999. An empirical examination of the form of the relationship between multinationality and performance. Journal of International Business Studies 30(1): 173-188.

Granovetter M. 1985. Economic action and social structure: the problem of embeddedness. American Journal of Sociology 91: 481-510.

Granovetter M. 1992. Problems of explanation in economic sociology. In Networks and Organizations: Structure, Form and Action, Nohria NN, Eccles RG (eds). Harvard Business School Press: Boston, MA; 25-56.

Greene WH. 1997. Econometric Analysis. Prentice-Hall: Upper Saddle River, NJ.

Griliches Z. 1990. Patent statistics as economic indicator: a survey. Journal of Economic Literature 27: 1661-1707.

Hagedoorn J. 1993. Understanding the rationale of strategic technology partnering: interorganizational modes of cooperation and sectoral differences. Strategic Management Journal 14(5): 371-385. 
Hagedoorn J, Duysters G. 2002. External sources of innovative capabilities: the preference for strategic alliances or mergers and acquisitions. Journal of Management Studies 39(2): 167-188.

Hargadon A, Sutton RI. 1997. Technology brokering in a product development firm. Administrative Science Quarterly 42: 716-749.

Hitt MA, Bierman L, Uhlenbruck K, Shimizu K. 2006. The importance of resources in the internationalization of professional service firms: the good, the bad, and the ugly. Academy of Management Journal 49(6): 1137-1157.

Hitt MA, Hoskisson RE, Kim H. 1997. International diversification: effects on innovation and firm performance in product-diversified firms. Academy of Management Journal 40(4): 767-798.

Hymer SH. 1976. The International Operations of National Firms: A Study of Direct Investment. MIT Press: Cambridge, MA.

Isenberg DJ. 2008. The global entrepreneur. Harvard Business Review 86(12): 107-110.

Johanson J, Vahlne J. 1977. The internationalization process of the firm-a model of knowledge development and increasing foreign market commitments. Journal of International Business Studies 8(1): 23-32.

Johanson J, Vahlne J. 1990. The mechanism of internationalisation. International Marketing Review 7(4): 11-24.

Johanson J, Vahlne J. 2003. Business relationship learning and commitment in the internationalization process. Journal of International Entrepreneurship 1: 83-101.

Jones MV, Coviello NE. 2005. Internationalisation: conceptualising an entrepreneurial process of behaviour in time. Journal of International Business Studies 36: 284-303.

Jonsson A, Elg U. 2006. Knowledge and knowledge sharing in retail internationalization: Ikea's entry into Russia. International Review of Retail 16(2): 239-256.

Knight GA, Cavusgil ST. 2004. Innovation, organizational capabilities, and the born-global firm. Journal of International Business Studies 35(2): 124-141.

Koka BR, Prescott JE. 2002. Strategic alliances as social capital: a multidimensional view. Strategic Management Journal 23(9): 795-816.

Larson A. 1992. Network dyads in entrepreneurial settings: a study of the governance of exchange relationships. Administrative Science Quarterly 37: 76-104.

Lazer D, Friedman A. 2007. The network structure of exploration and exploitation. Administrative Science Quarterly 52: 667-694.

Lechner C, Dowling M. 2003. Firm networks: external relationships as sources for the growth and competitiveness of entrepreneurial firms. Entrepreneurship \& Regional Development 15: 1-26.
Lee C, Lee K, Pennings JM. 2001. Internal capabilities, external networks, and performance: a study on technology-based ventures. Strategic Management Journal, JuneJuly Special Issue 22: 615-640.

Leung K, Bhagat RS, Buchan NR, Erez M, Gibson CB. 2005. Culture and international business: recent advances and their implications for future research. Journal of International Business Studies 36: 357-378.

Levin DZ, Cross R. 2004. The strength of weak ties you can trust: the mediating role of trust in effective knowledge transfer. Management Science 50(11): 1477-1490.

Li T, Calantone RJ. 1998. The impact of market knowledge competence on new product advantage: conceptualization and empirical examination. Journal of Marketing 62(4): 13-29.

Liebeskind JP, Oliver AL, Zucker L, Brewer M. 1996. Social networks, learning and flexibility: sourcing scientific knowledge in new biotechnology firms. Organization Science 7(4): 428-443.

Lord MD, Ranft AL. 2000. Organizational learning about new international markets: exploring the internal transfer of local market knowledge. Journal of International Business Studies 31(4): 573-589.

Lu JW, Beamish PW. 2001. The internationalization and performance of SMEs. Strategic Management Journal, June-July Special Issue 22: 565-586.

Makino S, Delios A. 1996. Local knowledge transfer and performance: implications for alliance formation in Asia. Journal of International Business Studies 27(5): 905-927.

McDougall PP. 1989. International versus domestic entrepreneurship: new venture strategic behavior and industry structure. Journal of Business Venturing 4(6): 387-400.

McDougall PP, Shane S, Oviatt BM. 1994. Explaining the formation of international new ventures: the limits of theories from international business research. Journal of Business Venturing 9(6): 469-487.

Moen O, Servais P. 2002. Born global or gradual global? Examining the export behavior of small and mediumsized enterprises. Journal of International Marketing 10(3): 49-72.

Morck R, Yeung B. 1992. Internalization: an event study test. Journal of International Economics 33(1-2): 41-56.

Mowery DC, Oxley JE, Silverman BS. 1996. Strategic alliances and interfirm knowledge transfer. Strategic Management Journal, Winter Special Issue 17: 77-91.

Nordberg M, Campbell AJ, Verbeke A. 1996. Can marketbased contracts substitute for alliances in high technology markets. Journal of International Business Studies 27(5): 963-979.

Oviatt BM, McDougall PP. 1995. Global start-ups: entrepreneurs on a worldwide stage. Academy of Management Executive 9(2): 30-44. 
Oviatt BM, McDougall PP. 2005. Defining international entrepreneurship and modeling the speed of internationalization. Entrepreneurship Theory \& Practice 29(5): 537-553.

Pisano GP. 1989. Using equity participation to support exchange: evidence from the biotechnology industry. Journal of Law, Economics and Organization 35: 109-126.

Plunkett JW. 2001. Plunkett's Biotech \& Genetics Industry Almanac: The Only Comprehensive Guide to Biotech Companies and Trends. Plunkett Research: Houston, TX.

Portes A, Sensenbrenner J. 1993. Embeddedness and immigration: notes on the social determinants of economic action. American Journal of Sociology 98: 1320-1350.

Powell WW, Koput KW, Smith-Doerr L. 1996. Interorganizational collaboration and the locus of innovation: networks of learning in biotechnology. Administrative Science Quarterly 41: 116-145.

Qian G, Li L. 2003. Profitability of small- and mediumsized enterprises in high-tech industries: the case of the biotechnology industry. Strategic Management Journal 24(9): 881-887.

Reagans R, McEvily B. 2003. Network structure and knowledge transfer: the effects of cohesion and range. Administrative Science Quarterly 48(2): 240-267.

Reagans R, Zuckerman EW. 2001. Networks, diversity, and productivity: the social capital of corporate R\&D teams. Organization Science 12(4): 502-517.

Reuber AR, Fischer E. 1997. The influence of the management team's international experience on the internationalization behaviors of SMEs. Journal of International Business Studies 28(4): 807-825.

Rodan S, Galunic C. 2004. More than network structure: how knowledge heterogeneity influences managerial performance and innovativeness. Strategic Management Journal 25(6): 541-562.

Roth MS, Jayachandran S, Dakhli M, Colton DA. 2009. Subsidiary use of foreign marketing knowledge. Journal of International Marketing 17(1): 1-29.

Rothaermel FT, Deeds DL. 2004. Exploration and exploitation alliances in biotechnology: a system of new product development. Strategic Management Journal 25(3): 201-221.

Rowley T, Behrens D, Krackhardt D. 2000. Redundant governance structures: an analysis of structural and relational embeddedness in the steel and semiconductor industries. Strategic Management Journal, March Special Issue 21: 369-386.

Rubin DB. 1987. Multiple Imputation for Nonresponse in Surveys. Chapman and Hall: New York.

Santoro MD, McGill JP. 2005. The effect of uncertainty and asset co-specialization on governance in biotechnology alliances. Strategic Management Journal 26(13): 1261-1269.
Sapienza HJ, Autio E, George G, Zahra S. 2006. A capabilities perspective on the effects of early internationalization on firm survival and growth. Academy of Management Review 31(4): 914-933.

Sapienza HJ, De Clercq D, Sandberg WR. 2005. Antecedents of international and domestic learning effort. Journal of Business Venturing 20(4): 437-457.

Schilling MA, Phelps CC. 2007. Interfirm collaboration networks: the impact of large-scale network structure on firm innovation. Management Science 53: 1113-1126.

Shan W. 1990. An empirical analysis of organizational strategies by entrepreneurial high-technology firms. Strategic Management Journal 11(2): 129-139.

Shan W, Walker G, Kogut B. 1994. Interfirm cooperation and startup innovation in the biotechnology industry. Strategic Management Journal 15(5): 387-394.

Shane S. 2000. Prior knowledge and the discovery of entrepreneurial opportunities. Organization Science 11(4): 448-469.

Shrader RC, Oviatt BM, McDougall PP. 2000. How new ventures exploit trade-offs among international risk factors: lessons for the accelerated internationalization of the 21st century. Academy of Management Journal 43(5): 1227-1247.

Simonin BL. 1999. Transfer of marketing know-how in international strategic alliances: an empirical investigation of the role and antecedents of knowledge ambiguity. Journal of International Business Studies 30: 463-490.

Simons T, Ingram P. 2000. The kibbutz for organizational behavior. Research in Organizational Behavior 22: 283-343.

Slotte-Kock S, Coviello N. 2010. Entrepreneurship research on network processes: a review and ways forward. Entrepreneurship Theory and Practice 34(1): 31-57.

Smith HL, Dickson K, Smith SL. 1991. "There are two sides to every story": innovation and collaboration within networks of large and small firms. Research Policy 20: 457-468.

Soda G, Usai A, Zaheer A. 2004. Network memory: the influence of past and current networks on performance. Academy of Management Journal 47(6): 893-906.

Soh P. 2003. The role of networking alliances in information acquisition and its implications for new product performance. Journal of Business Venturing 18(6): 727-744.

Sorenson JB, Stuart TE. 2000. Aging, obsolescence, and organizational innovation. Administrative Science Quarterly 45(1): 81-112.

Spencer JW. 2003. Firms' knowledge-sharing strategies in the global innovation system: empirical evidence from the flat panel display industry. Strategic Management Journal 24(3): 217-233. 
Stuart TE. 2000. Interorganizational alliances and the performance of firms: a study of growth and innovation rates in a high-technology industry. Strategic Management Journal 21(8): 791-811.

Sullivan D. 1994. Measuring the degree of internationalization of a firm. Journal of International Business Studies 25: 493-513.

Tallman S, Li J. 1996. Effects of international diversity and product diversity on the performance of multinational firms. Academy of Management Journal 39(1): 179-196.

Todorova G, Durisin B. 2007. Absorptive capacity: valuing a reconceptualization. Academy of Management Review 32(3): 774-786.

Tsang EWK. 2002. Acquiring knowledge by foreign partners from international joint ventures in a transition economy: learning-by-doing and learning myopia. Strategic Management Journal 23(9): 835-854.

Walker G, Kogut B, Shan W. 1997. Social capital, structural holes and the formation of an industry network. Organization Science 8(2): 109-125.

Wooldridge JM. 2002. Econometric Analysis of Cross Section and Panel Data. MIT Press: Cambridge, MA.

Yli-Renko H, Autio E, Sapienza HJ. 2001. Social capital, knowledge acquisition, and knowledge exploitation in young technology-based firms. Strategic Management Journal, June-July Special Issue 22: 587-613.

Yu T, Cannella AA. 2007. Rivalry between multinational enterprises: an event history approach. Academy of Management Journal 50(3): 665-686.

Zaheer A, Bell GG. 2005. Benefiting from network position: firm capabilities, structural holes, and performance. Strategic Management Journal 26(8): 809-825.

Zaheer A, George VP. 2004. Reach out or reach within? Performance implications of alliances and location in biotechnology. Managerial and Decision Economics 25: 437-452.

Zaheer S. 1995. Overcoming the liability of foreignness. Academy of Management Journal 38(2): 341-363.

Zahra SA. 1996. Technology strategy and new venture performance: a study of corporate-sponsored and independent biotechnology ventures. Journal of Business Venturing 11(4): 289-321.

Zahra SA, George G. 2002a. Absorptive capacity: a review, reconceptualization, and extension. Academy of Management Review 27(2): 185-203.

Zahra SA, George G. 2002b. International entrepreneurship: the current status of the field and future research agenda. In Strategic Entrepreneurship: Creating an Integrated Mindset, Hitt M, Ireland D, Sexton D, Camp M (eds). Blackwell: Oxford, UK; 255-288.

Zahra SA, Ireland RD, Hitt MA. 2000. International expansion by new venture firms: international diversity, mode of market entry, technological learning, and performance. 